University for Business and Technology in Kosovo

UBT Knowledge Center

Oct 28th, 9:00 AM - 10:30 AM

\title{
The Usage of Edible Additives with Different Gluten Quality in Baking Products
}

\section{Sana}

Aleksander Moisiu University

A. Sinani

Agricultural University of Tirana

Follow this and additional works at: https://knowledgecenter.ubt-uni.net/conference

Part of the Food Science Commons

\section{Recommended Citation}

Sana, M. and Sinani, A., "The Usage of Edible Additives with Different Gluten Quality in Baking Products" (2017). UBT International Conference. 160.

https://knowledgecenter.ubt-uni.net/conference/2017/all-events/160

This Event is brought to you for free and open access by the Publication and Journals at UBT Knowledge Center. It has been accepted for inclusion in UBT International Conference by an authorized administrator of UBT Knowledge Center. For more information, please contact knowledge.center@ubt-uni.net. 


\title{
THE USAGE OF EDIBLE ADDITIVES WITH DIFFERENT GLUTEN OUALITY IN BAKING PRODUCTS
}

\author{
M.Sana ${ }^{1}$ A.Sinani ${ }^{2}$ \\ ${ }^{1}$ Aleksander Moisiu University, Durres, Albania \\ ${ }^{2}$ Faculty of Food Biotechnology, Agriculture University of Tirana, Albania
}

\begin{abstract}
One of the dominating factors in the foods quality besides the wheat quality, grinding and baking technology, is also the impact of edible additives in these products.

These agents are nothing but chemical base products, that change the physical and rheological properties of baking products with the help of oxidation and reduction reactions placed in dough. The structures and quantitative formations of gluten proteins define dough qualities for cakes, biscuits and wafers.Reductants are substances, that soften gluten, weakening its links.Reductans react with disulfide SS in dough.Their impact is the reduction of the general molecular weight of the gluten proteins aggregates. The usage of reductans leads in the increasement of dough volume.The fixed gas inside the dough can develop a soft dough.

The first scale of the reaction is the interaction of reductans with the gluten proteins. This reaction is an exchange SH/SS that releases a protein unit and leaves a SS link between protein and reductant.This SS part can interact with the reductant,leaving the second protein group free and giving the oxidized form to it.

The most used reductants are L-Cysteins and Metabisulfite of Sodium.From the evidences made, results that the usage of these reductants leads to an advanced increasement of the dough and to a great form of the ultimate product.Based on our research for produced wheats in our country and those which are imported, for a certain flour radius and choice, the research is done among the evulation of redox agents interaction based upon the production of products like cakes,biscuits,wafers etc.
\end{abstract}

Keywords: The quality of products, edible additives, dough rheology

\section{INTRODUCTION}

Nowadays we are looking a variety of dough-based products which are increasing day by day. This is due to bring us benefits that additives. In itself redox agents are all those chemicals which give reactions which occur donation or taking electrons, then we change the number of oxidation. These additives are nothing but chemical-based products which the oxidation or reduction reactions that develop in the dough, the physical properties that differ reologjike. So we separate redox agents on oxidative and reductive. The oxidation mainly affects in -SS-links of amino acids that are components of gluten. Oxidation of both hydrogen sulfide groups (thiols) results in the formation of a disulfide bridge between long sections of the gluten molecule or different molecules of gluten. This causes the strengthening of the protein that consists of improving pulp quality depending on the ratio between L-ascorbic acid and L-cisteinës that is studied. It is proved that the addition of $\mathrm{L}$-ascorbic acid will increase in flour water absorption level while increasing the L-cisteinës give the opposite effect. L-cysteine improves the specific volume of bread. 
Optimal ratio of L-ascorbic acid and L-cisteinës is 60:40 ppm. Bread, which is added L-ascorbic acid and L-cysteine $\quad$ (60:40 ppm by weight of flour), has a specific maximum volume. By cysteine adding tends to increase the specific volume of bread, while by cisteinës adding in more than $50 \mathrm{ppm}$ passes in the opposite effect. Sensory evaluation of bread made with ascorbic acid, up to $60 \mathrm{ppm}$, gives an optimal volume and other parameters, while adding about $60 \mathrm{ppm}$ makes these ratings to decline. This can result in the acceleration of separation of gluten from the cysteine which also requires separation of gluten during mixing and forming $-\mathrm{S}-\mathrm{H}$ group, which gives a soft dough, sticky and less elastic.

\section{MATERIALS AND METHODS}

For the production of bread are produced using variety of Luna,Dajti and Progres, the percentage set by each cultivar. Depending on the parameters qualitative and quantitative are studied the impact of additives to improve the rheology properties in pasta and bread production. The study is conducted in flours type 600-650 produced by flour factory in Tirana, while the production of bread is made in the factory BUKA Sh.A. and in the laboratory of the flour factory "Vora". Breadmeaking tests are carried out with samples of flour Reference and others with the addition of supplements. To perform these tests are used:

$>6$ Reference samples - are produced various forms of bread with no additives. Reference flour is produced by mixing 60\% (Dajti and Progres) and Luna $40 \%, 70 \%$ range and ash content $0.58-0.60$.

6 samples - with additional of ascorbic acid $18 \mathrm{ppm}$.

> 6 samples - with four additives: $17 \mathrm{ppm} \alpha$-amylase, $15 \mathrm{ppm}$ cysteine, hemi cellulose $36 \mathrm{ppm}$ and $18 \mathrm{ppm}$ ascorbic acid.

Assessing the quality of samples is done according to ISO standard, using physical methods, chemical, rheological and technological. For determination of leguminous seeds, such as dirt sizes, foreign aromas, species and varieties are referred to S SH 605:2000, to determining the humidity of the grain is referred to S SH 712:2000, evaluation and characteristics of wheat bread by S SH 1411:1987, evaluation and characteristics of wheat flour by S SH 1455:1987, pasta and evaluation of their characteristics SH S 1460:1987, and sampling the bread according to S SH 1499:1987. To determine the rheological characteristics are used by 300 grams of flour for each analysis with Brabender Farinograph, Chopin Alveograph and Extensograph.

\section{RESULTS AND ANALYSIS}

\section{Characteristics of wheat}

For the study of additives in the flour are take in the study the wheats originally from Albania Luna, Dajti and Progres,supplying flour mills in our country.In these wheats following parameters are studied (Table 1): 
Table 1: The qualitative indicators for studying of wheat

\begin{tabular}{|l|c|c|c|c|c|c|c|}
\hline \multirow{2}{*}{$\begin{array}{l}\text { Wheat } \\
\text { variety }\end{array}$} & \multicolumn{7}{|c|}{ The quality of wheat } \\
\cline { 2 - 8 } & $\begin{array}{c}\text { Hektolitre } \\
\text { Weight } \\
\mathrm{kg} / \mathrm{hL}\end{array}$ & $\begin{array}{c}\text { Humidit } \\
\mathrm{y} \\
(\%)\end{array}$ & $\begin{array}{c}\text { Protein } \\
(\%)\end{array}$ & $\begin{array}{c}\text { F.N } \\
(\mathrm{sek})\end{array}$ & $\begin{array}{c}\text { Amylaze } \\
\text { AU }\end{array}$ & $\begin{array}{c}\text { Gluten } \\
\%\end{array}$ & $\begin{array}{c}\mathrm{W} \\
\mathrm{P} / \mathrm{L}\end{array}$ \\
\hline Luna & 79 & 12.8 & 11.9 & 372 & 590 & 22 & 200 \\
\hline Dajti & 81 & 13.4 & 14 & 291 & 400 & 30 & 300 \\
\hline Progres & 77 & 13.6 & 13.7 & 529 & 690 & 27 & 210 \\
\hline
\end{tabular}

- According to Table 1 the highest content of protein is in Dajti wheat, as well as in W higher. Given the quality of Progres and Dajti wheat, which have very good parameters, will use this mixture ratio:

$$
35 \% \text { Progres }+25 \% \text { Dajti }+40 \% \text { Luna }
$$

- Assessing the rheology qualities of wheat cultivars is very important to determining the amounts of improvements (redox agents) in the pasta and flour for bread production.

- Doughs that are strong not allow the development of pores and have high density, forming a small volume of food, while doughs who are weak cannot keep air bubbles within the dough, and therefore larger pores are formed in bread.

\section{Rheological qualities of wheat cultivars}

Assessing of the rheological qualities at wheat cultivars is very important for determining of improvement amounts on flour and dough in bread production. Strong dough not allow the development of pores and have high density, forming a small volume of bread, while dough that are weak cannot keep air bubbles within the dough and thus form large pores in the bread.

Farinografi measure the dough consistency by mixing it with constant speed and water absorption, which enables achieving this consistency.

Table 2: Qualitative indicators in Farinograph

\begin{tabular}{|l|c|c|c|c|}
\hline \multirow{3}{*}{ Cultivars } & \multicolumn{4}{|c|}{ Farinograph } \\
\cline { 2 - 5 } & $\begin{array}{c}\text { Water } \\
\text { absorption } \\
(\%)\end{array}$ & $\begin{array}{c}\text { Development } \\
(\mathrm{min})\end{array}$ & $\begin{array}{c}\text { Stability } \\
(\mathrm{min})\end{array}$ & $\begin{array}{c}\text { Smoothing } \\
\text { degree } \\
\text { (FU) }\end{array}$ \\
\hline Luna & 54.7 & 1.7 & 4.7 & 96 \\
\hline Dajti & 52.9 & 2.8 & 10.8 & 70 \\
\hline Progres & 52.8 & 9.5 & 11.9 & 74 \\
\hline
\end{tabular}

From the data of table 2 shows that Luna cultivar has water absorption greater compare with Progres and Dajti. Development time and stability is greater for Progres cultivar and Dajti, compared to Luna, while smoothing degree of Dajti cultivar is smaller than Progres and Luna cultivar. This indicates that Luna cultivar is a soft wheat cultivar and Progres and Dajti cultivars are wheat with glasses between $35-45 \%$, which confirms the results. So, it is necessary using of redox agent in these sorts of wheats. 
Table 3: Qualitative indicators in Extensograph

\begin{tabular}{|c|c|c|c|c|}
\hline \multirow{2}{*}{$\begin{array}{c}\text { Flour } \\
\text { Cultivars }\end{array}$} & $\begin{array}{c}\text { Resistance in } \\
\text { tow (EU) }\end{array}$ & $\begin{array}{c}\text { Elasticity } \\
(\mathrm{mm})\end{array}$ & $\mathrm{R} / \mathrm{E}$ & $\begin{array}{c}\text { Energy } \\
\left(\mathrm{cm}^{2}\right)\end{array}$ \\
\hline Luna & 239 & 141 & 1.7 & 53 \\
\hline Dajti & 458 & 156 & 2.94 & 128 \\
\hline Progres & 313 & 161 & 1.94 & 93 \\
\hline
\end{tabular}

From the data analysis with extensograph seen that significant changes in the pulp and extesibility resistance which affected not only by the personal qualities of the flour (which depend on cultivars that analyze their radius), but the impact of has highlighted the dough especially ascorbic acid redox factors. By comparing data extensograph have seen a significant increase in the resistance of dough when he add $18 \mathrm{ppm}$ ascorbic acid, which reaches up to $590 \mathrm{EU}$, from EU to 200-400 cases with other supplements. These data analysis performed orient us to use these flour, especially when energy reaches $590 \mathrm{EU}$ for use in industry mix pasta.

Rheological characteristic of referent flour and flour with additives

Tabela 4: Comparative impact of dough improvement in Farinograph

\begin{tabular}{|l|c|c|c|c|}
\hline \multirow{2}{*}{ Flour } & \multicolumn{4}{|c|}{ Farinogaph } \\
\cline { 2 - 5 } & $\begin{array}{c}\text { Water } \\
\text { absorption } \\
(\%)\end{array}$ & $\begin{array}{c}\text { Development } \\
(\mathrm{min})\end{array}$ & $\begin{array}{c}\text { Stability } \\
(\mathrm{min})\end{array}$ & $\begin{array}{c}\text { Smoothing } \\
\text { degree } \\
(\mathrm{FU})\end{array}$ \\
\hline Reference Flour & 57.9 & 1.39 & 3.6 & 112 \\
\hline Reference + $\alpha$-amylase & 57 & 1.3 & 2.4 & 158 \\
\hline Reference+Cysteine & 56 & 1.38 & 2.4 & 109 \\
\hline Reference+Hemycelullose & 55.1 & 2 & 6.5 & 101 \\
\hline Reference+ Ascorbic acid & 58 & 1.8 & 5.1 & 81 \\
\hline $\begin{array}{l}\text { Reference + } \\
\text { components }\end{array}$ & 59 & 2.21 & 7.45 & 102 \\
\hline
\end{tabular}

From the above data shows that the reference flour used to produce pasta rheological good quality needs with the addition of additives oksido-reduction actions. By the addition of $\alpha$-amylases rate amounts to $158 \mathrm{FU}$ mitigation and stability $2.4 \mathrm{~min}$., While the four viscosity when used mixed together have a significant increase in the degree of stability which amounts to $7.45 \mathrm{~min}$. 
Table 5: Comparative impact of dough improvement in Extensograph

\begin{tabular}{|l|c|c|c|c|}
\hline \multirow{2}{*}{ Flour } & \multicolumn{4}{|c|}{ Estensograma } \\
\cline { 2 - 5 } & $\begin{array}{c}\text { Resistance } \\
\text { in tow } \\
(\mathrm{EU})\end{array}$ & $\begin{array}{c}\text { Elasticity } \\
(\mathrm{mm})\end{array}$ & $\mathrm{R} / \mathrm{E}$ & $\begin{array}{c}\text { Energy } \\
\left(\mathrm{cm}^{2}\right)\end{array}$ \\
\hline Reference Flour & 358 & 131 & 2.74 & 70 \\
\hline $\begin{array}{l}\text { Reference } \\
\text { amylase }\end{array}$ & 341 & 138 & 2.64 & 64 \\
\hline Reference+Cysteine & 190 & 139 & 1.33 & 41 \\
\hline $\begin{array}{l}\text { Reference+Hemycelul } \\
\text { lose }\end{array}$ & 253 & 140 & 1.77 & 61 \\
\hline $\begin{array}{l}\text { Reference+ ascorbic } \\
\text { acid }\end{array}$ & 590 & 100 & 6.63 & 83 \\
\hline $\begin{array}{l}\text { Reference + } \\
\text { components }\end{array}$ & 362 & 139 & 3.46 & 88 \\
\hline
\end{tabular}

Even the data of Extensograph seen that from the combined used of four redox agent is increased rheology of these flours increase, such as resistance, elasticity, and especially the ratio R /E, which reaches a value of 3:46 that is considered optimum value.

\section{Graphic view in Farinograph and Extensograph}

Laboratory analysis of flours by extensograph

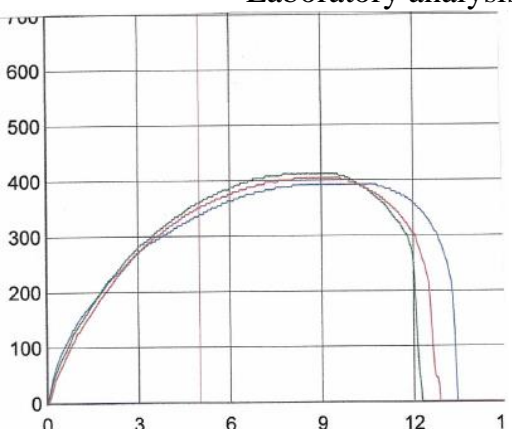

Flour free additives (Reference)

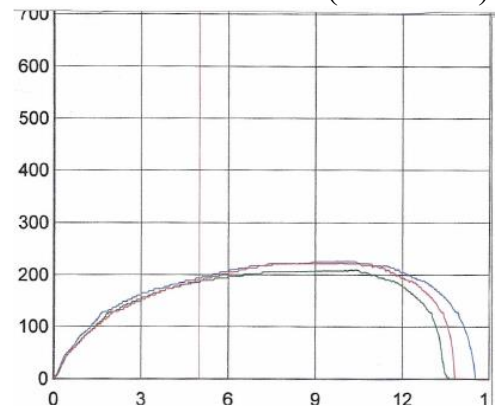

Reference +15 ppm cysteine

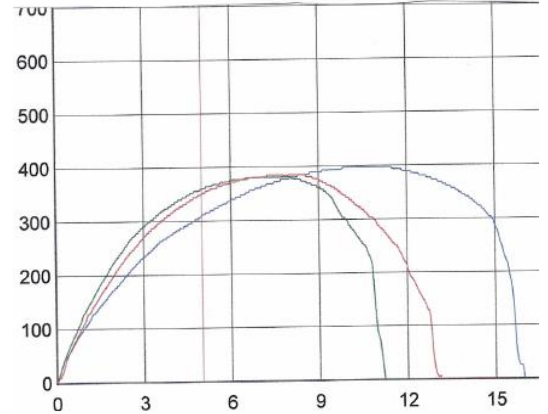

Reference +17 ppm $\alpha$-amylase

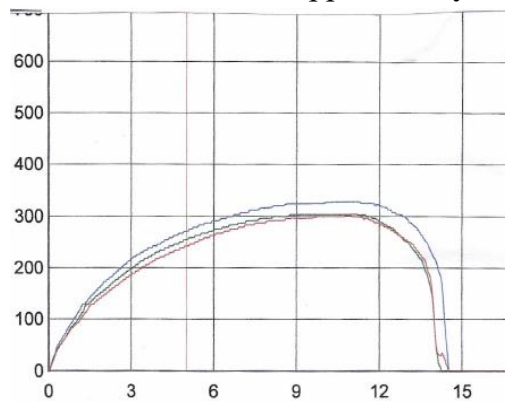

Reference +36 ppm hemicellulose 


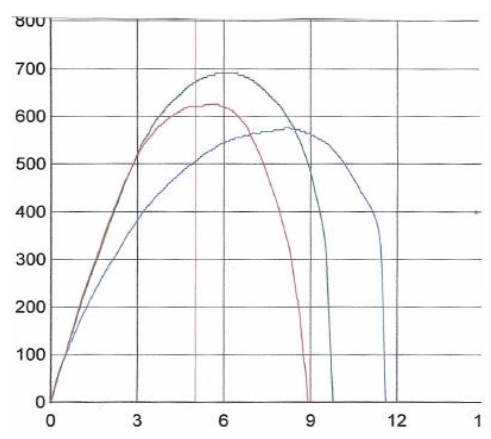

Reference +18 ppm ascorbic acid

\section{Flour analysis with Farinograph}

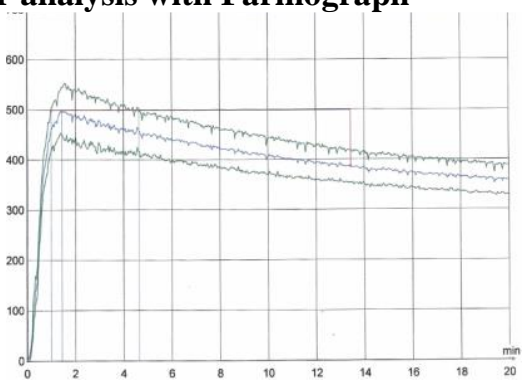

Reference flour

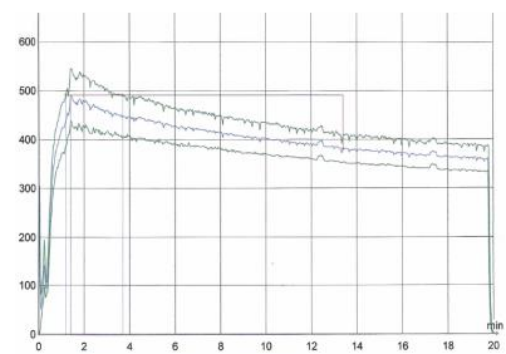

Reference +15 ppm cysteine

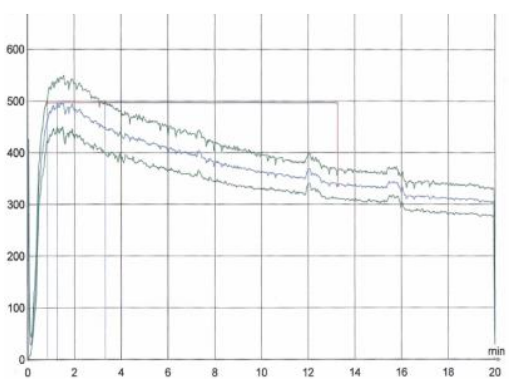

Reference flour +17 ppm $\alpha$-amylase

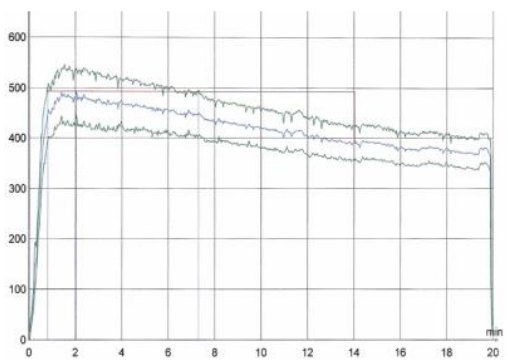

Reference +36 ppm Hemicellulose 


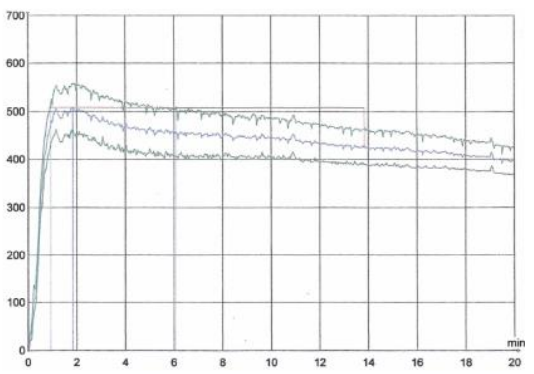

Reference +18 ppm ascorbic acid

Graphic view with four additives in Extensograph and Farinograph

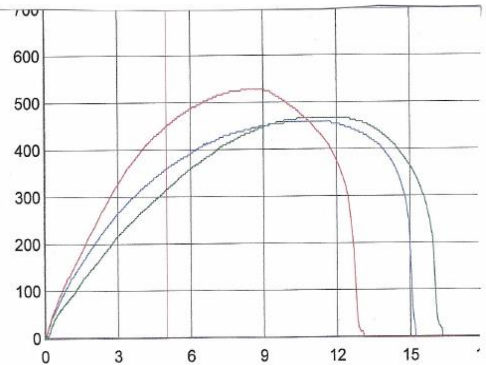

Extensograph

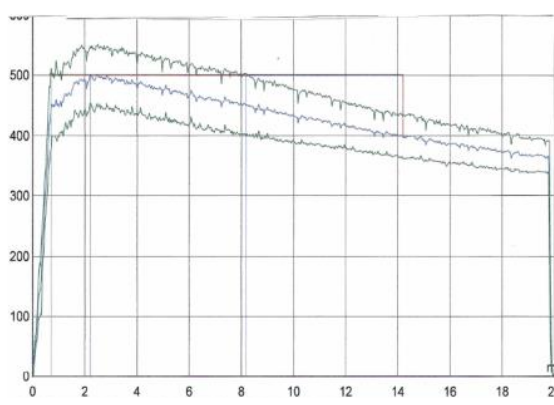

Farinograph

Breadmaking qualities of the Reference flour and by adding to Farinograf, according to the above graphics are classified with sufficient quality declines in the pulp 50-70 FU and stability no less than 5 minutes, which corresponds to adding ascorbic acid at $18 \mathrm{ppm}$, while by using of four additives together reach $59 \%$ water absorption, dough development and stability of 7.45 min that are indicators of pulp rheology optimal.

Photos illustrating the bread without treatment and treated with additives

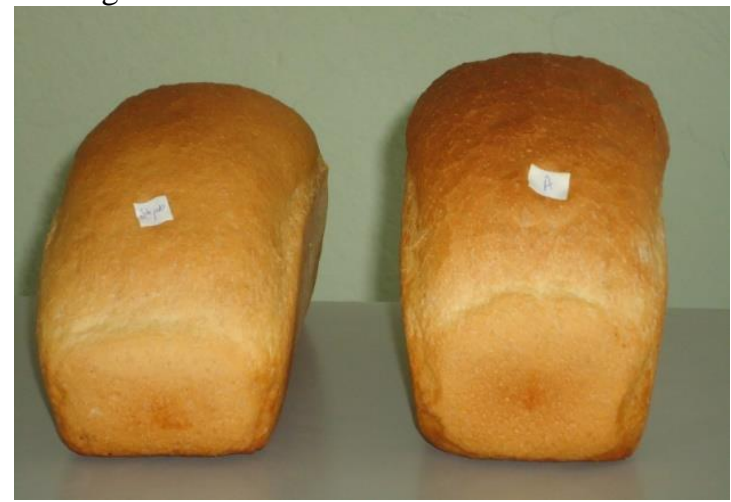

Reference +17 ppm $\alpha$-amylase 

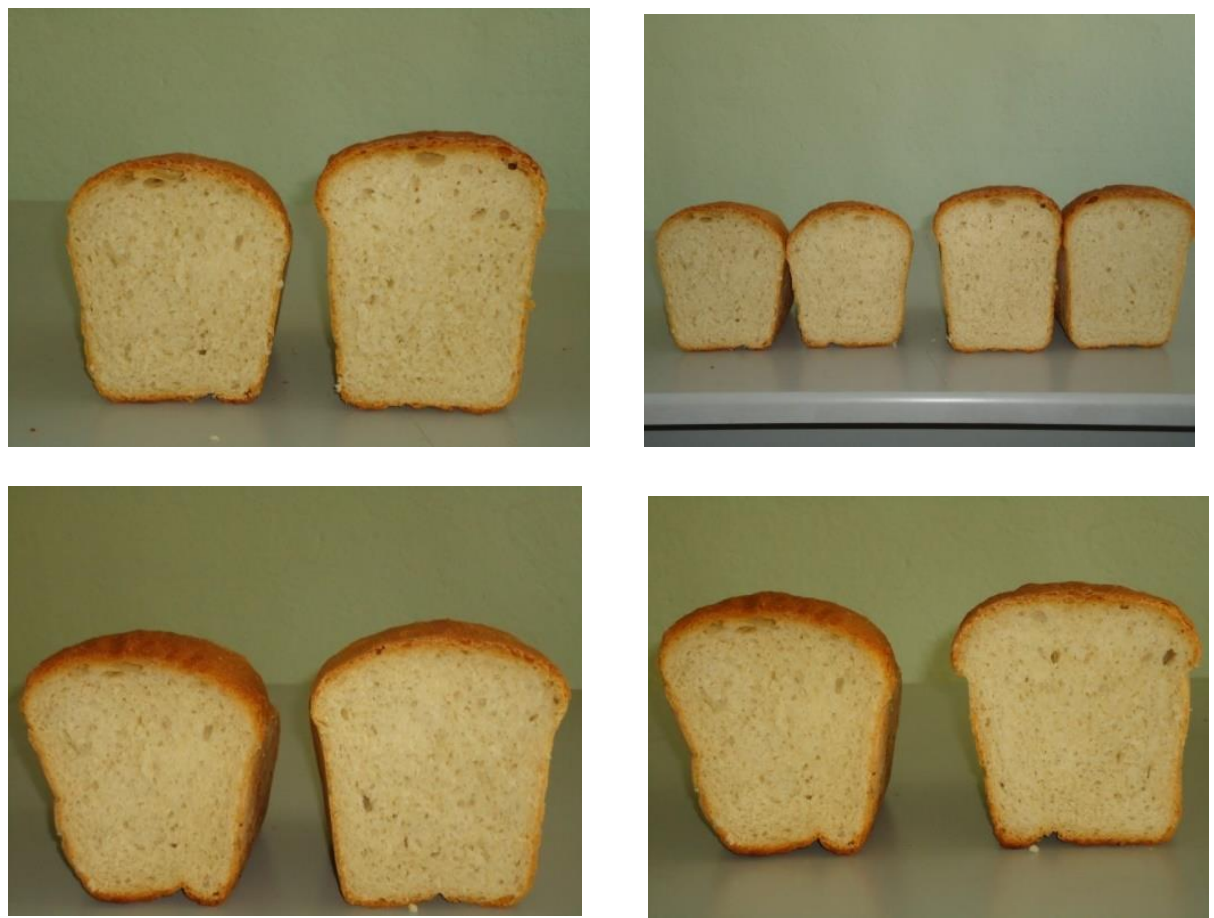

Reference+ 15 ppm Cysteine

Reference +36 ppm Hemicellulose

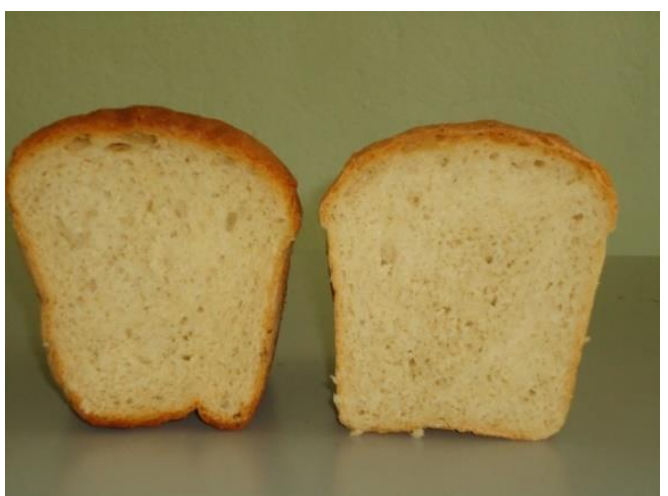

Reference +18 ppm ascorbic acid 

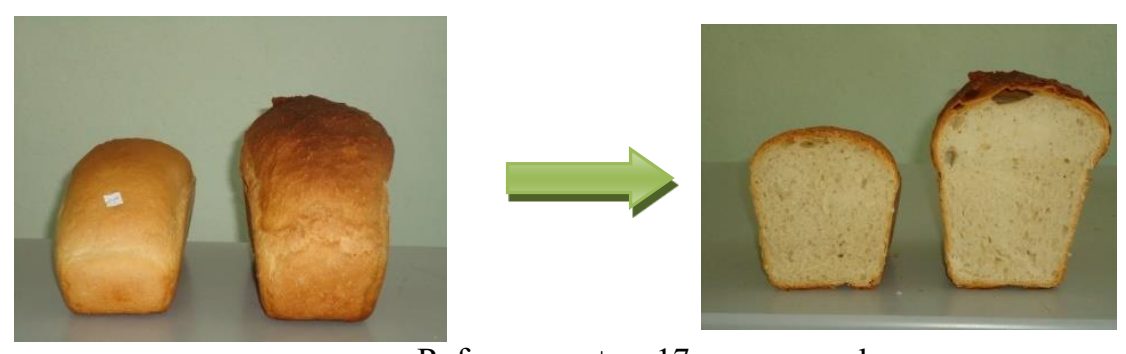

Reference $+17 \mathrm{ppm} \alpha$-amylase

15 ppm cysteine

36 ppm hemycellulose

18 ppm ascorbic acid

Table 6. Characteristics of dough and qualitative properties of bakery products with and without additives.

\begin{tabular}{|c|c|c|c|}
\hline $\begin{array}{c}\text { Dough } \\
\text { characteristics }\end{array}$ & Reference flour & $\begin{array}{c}\text { Flour with } \\
\text { ascorbic acid }\end{array}$ & $\begin{array}{c}\text { Flour with } \\
\text { four additives }\end{array}$ \\
\hline $\begin{array}{c}\text { Water absorption } \\
\text { capacity }(\%)\end{array}$ & 60.6 & 62.1 & 63.8 \\
\hline Dough's structure & Normal & improved & improved \\
\hline Dough's tolerance & Normal & $\begin{array}{l}\text { very brassy to } \\
\text { kneading }\end{array}$ & high \\
\hline $\begin{array}{l}\text { Kneading duration } \\
\text { (min) }\end{array}$ & according to prescription & low & low \\
\hline $\begin{array}{c}\text { Bread volume } \\
\left(\mathrm{cm}^{3}, 100 \mathrm{~g}\right)\end{array}$ & 261 & 322 & 310 \\
\hline Porosity $(\%)$ & 77.4 & 81.7 & 80.2 \\
\hline Elasticity (\%) & 97 & 97 & 98 \\
\hline Humidity (\%) & 40.2 & 43 & 44.3 \\
\hline $\begin{array}{l}\text { Organoleptic } \\
\text { properties: } \\
\text { 1. aspect } \\
\text { 2. crust } \\
\text { 3. crumb } \\
\text { 4. } \quad \text { taste and } \\
\text { aroma }\end{array}$ & $\begin{array}{cc}\text { - } & \text { round, raised } \\
\text { - } & \text { crispy, shiny, } \\
\text { golden color } \\
\text { uniform } \\
\text { distribution of } \\
\text { pores, elastic, not } \\
\text { wet by feel } \\
\text { - } \quad \text { agreeable }\end{array}$ & \multicolumn{2}{|c|}{$\begin{array}{c}\text { - } \quad \text { round, well raised } \\
\text { - } \quad \text { crispy, shiny, yellow- } \\
\text { golden color } \\
\text { - } \quad \text { fine pores with } \\
\text { uniform distribution, } \\
\text { soft, elastic, dry by } \\
\text { feel, brighter color } \\
\text { - agreeable with walnut } \\
\text { aroma }\end{array}$} \\
\hline
\end{tabular}

By table 6 shows that the basic characteristics of the dough produced by Reference flour and its mixing with additives results that bread produced without the using of supplements have a lower volume, while those with additions not only increase the volume but they have a higher porosity, up to 81.5 , and resilience to 98 . Further, significant improvements on quality have organoleptic indicators also. 


\section{CONCLUSION}

Using of redox agents in bread industry is necessary, particularly when we can not harmonize with different quality wheat.

Progres cultivar and Dajti have high elasticity and energy, but W is $210-300 \mathrm{P} / \mathrm{L}$, which makes necessary using of $\alpha$-amylase at $17 \mathrm{ppm}$.

From the survey data concluded that using of the four redox components affects in qualitative improvement of breadmaking, especially in increasing the stability of the dough up to $7.45 \mathrm{~min}$, compared with 3.6 min reference.

Using of L-ascorbic acid and L-cysteine, combined together, improve the quality of food better than their use alone. Optimal ratio of L-ascorbic acid and L-cysteine is 60:40 ppm. In this report the bread has a specific maximum volume and other parameters too good.

By comparative data in extensograph, to the Reference flour those with additive, have a significant improvement of energy growth $\left(\mathrm{cm}^{2}\right)$ from 70 to $88 \mathrm{~cm}^{2}$.

Combined improvement of redox factors, according to quality and range of wheat flour is necessary in the baking industry products.

\section{REFERENCES}

1. Shkenca dhe Teknologjia e Produkteve të Pjekjes - Sinani A, Tiranë 2009

2. Redox Biochemistry - Ruma Banerjee - University of Michigan

3. Journal of Agroalimentary Processes and Technologies-Edition 14

4. Analyses Food Science and Technology - www.afst.valahi.ro

5. Katalogu i standardeve shqiptare - Drejtoria e Përgjithshme e Standardizimit (DPS), Katalogu 2005

6. Wheat Quality Analyses of CROP - Ed. Wheat Board - Pretoria-Sud Africa

7. Metodi di analisi per il frumento e le farine- Ed.Associazione Agraria Romagnola-Bologna

8. Bordei, D., Burluc, R., (1998). Tehnologia si controlul calitatii in industria panificatiei. MEC, Universitatea "Dunarea de Jos" Galati

9. Costin, G.M., Segal, R. (1999). Alimente functionale. Ed. Academica, Galati, 298-303

10. Modoran, C. (2003). Tehnologia produselor fãinoase. Ed. AcademicPres, Cluj-Napoca, Romania 